DOI: $10.2478 / \mathrm{v} 10025-010-0003-\mathrm{Z}$

\title{
Application of mathematical modelling methods in the protection of groundwater environment
}

\author{
Marek ŚLESICKI
}

Institute of Meteorology and Water Management, Department of Water Management, ul. Podleśna 61, 01-673 Warszawa, Poland

\begin{abstract}
In the projects of protection of soil-water environment there is a need to combine and process large amount of information from various disciplines to estimate parameters of phenomena and to determine the range and time table of necessary undertakings.

Due to complex assessment of processes taking place in aquifers, mathematical modeling is the best tool supporting evaluation off pollution in the ground water environment. It is also an effective method of forecasting the risk associated with the harmful impact of objects polluting grounds and grounds waters.

Significant application of mathematical modeling is the use for the enlargement of information gathered in the process of recognition and assessment of condition that prevail in soil-water environment. Results of modeling, if appropriately presented, could be an important element of decision support system in environmental management.

This paper describes procedures for developing an environmental remediation decision support system by linking CADD and GIS software with the hydro geological flow and transport models.
\end{abstract}

Key words: contamination transport, environment protection, groundwater, mathematical modelling

\section{INTRODUCTION}

In order to effectively counteract the proceeding degradation of groundwater quality one needs to understand the processes affecting permeation of substances to these waters and to elaborate methods of their quantification.

The development of digital methods and increasing computing power of processors raised the importance of mathematical modelling in design and assessment of the efficiency of monitoring and purification of grounds and ground waters. Modern mathematical models allow for predicting the effects of restoration systems and for minimizing costs of proposed solution. Prognoses based on simulations might be used both as a basis for decisions on restoration and for formulating strategies of purification and prevention from pollution. Due to the complex assessment of processes taking place in aquifers, mathematical modelling is the best 
tool supporting evaluation of pollution in the ground-water environment. It is also an effective method of forecasting the risk associated with the harmful impact of objects polluting grounds and ground waters.

The main reason of ground water pollution is delivery and storage of pollutants in the ground and on its surface. Liquid wastes and leachates from solid wastes dumping sites have direct effect on groundwater quality. In Poland most practical applications of mathematical modelling pertain to the effect of these sources on the quality of ground waters (FIC and ŚLESICKI, 2001; Poradnik..., 2000; ŚLESICKI, 2007a; b).

\section{GENERAL CHARACTERISTICS OF GROUNDWATER SYSTEMS}

Hydrogeological system of underground catchment is characterised by a definite geometry and filtration properties. Knowledge of this system acquired from hydrogeological survey is a starting point in modelling filtration processes.

Simplified way of description of the modelled system is necessary for modelling purposes. In general, the system is divided into feeding (aeration) zone and resource (saturation) zone. The former involves all elements affecting the balance of groundwater resources. Modelling this zone involves selected processes taking place on the soil surface and affecting the amount of water that permeates downward as well as processes taking place between the surface and groundwater table that determine amounts and distribution of groundwater recharge. Modelling resource zone is aimed at describing the processes taking place beneath groundwater table and affecting the direction and amount of water flow.

Ground water pollutants may be defined as substances introduced by man which are absent in natural waters or occur in smaller amounts. Criteria of pollutants classification originate from their various properties like: chemical or biological type, state of matter, possibility of mixing or reacting with water, origin, toxicity, stability, way of permeation, range and type of their effects.

\section{MATHEMATICAL MODELLING OF POLLUTANT TRANSPORT}

In general, two basic classes of problems pertaining to flow of ground waters and transport of solutes can be distinguished when modelling groundwater resources.

Models of groundwater flow are intended to simulate water movement in a variably saturated porous medium. Typical applications of such models refer to the simulation of the effects of man-made and natural factors on the amount of groundwater resources and to the estimation of velocity pools needed to define advective waterways transporting solutes. 
Models of transport were created to enable simulation of solutes movement through variably saturated porous medium. Typical applications of these models involve studies on: migration of pollutants from dispersed and point sources, the effect of fertilisers and pesticides on water quality, environmental effects of surface and underground reservoirs.

Models of both flow conditions and pollutant transport in groundwater system may refer to all or to some elements by describing processes that take place in the recharge zone, in resource zone or in both. Description of modelled processes might be realised in one, two, quasi three or three dimensional space (GUTOWSKA-SIWIEC and ŚLESICKI, 2002).

Mathematical modelling of groundwater flow and transport and of pollutant behaviour in grounds and ground waters might be helpful in determining medium parameters, in studies on water dynamics, in resource analyses, in explaining and predicting the processes of pollutant migrations.

Methods of modelling are diverse: from simple analytical solutions based on simplified schemes and equations of flow and transport to complex numerical models simulating these processes in three dimensional heterogenic and anisotropic environments.

Two schemes differing in the way of description are usually used in advective-dispersion numerical models of transport. It is assumed that:

- migration of pollutants is a resultant of combined effect of two vector fields (velocity of advective stream of pollutant mass and dispersion velocity of pollutant stream) and numerical solution of the problem is obtained with the method of finite differences or finite elements,

- migration of pollutants is a sum of movements of particular particles resulting from their movement along the stream lines and moving away from this line due to dispersion. Numerical solution is obtained with the method of characteristics or modified method of characteristics.

Construction of a model properly reflecting modelled phenomena and numerically effective is usually a complex task. Complexity is mainly determined by: the size of modelled area and its geological structure and by the type and composition of polluting substances. Irrespective of local determinants one may formulate general algorithm of actions associated with the model construction and performed calculations. Properly carried model studies should be composed of the following stages.

- Preparatory stage (determining the study aim and collecting the input data). The aim of undertaken model studies is determined by the adoption of appropriate calculation scheme decisive for final selection of the calculation programme. All available data describing modelled object and its surrounding should be collected at this stage. 
- Selection of mathematical model. To accomplish the aims formulated in preparatory stage one may select one of the existing models or prepare the author's programme. Selected model should undergo preliminary verification consisting in comparison of numerical solution generated by the model with analytical solutions or with other numerical solutions.

- Construction of a model. In this stage the scope of modelling is being estimated through: division of modelled area into elements of calculation grid, selection of calculation time steps, establishment of borders, initial and edge conditions and preliminary selection of parameter values.

- Model calibration. Calibration is aimed at estimating to what degree results of calculations based on selected model agree with field measurements. Calibration is usually made with the method of consecutive approximations for various sets of parameters.

- Analysis of model sensitivity. Calibrated model bears a burden of error due to indeterminacy and of errors in the reproduction of spatial and temporal parameter distribution in studied area and inaccuracy of edge conditions. Analysis of model sensitivity is carried out to establish the effect of these errors on solution with the use of special methods and algorithms.

- Model verification. The model is verified to increase its reliability through calculations for some sets of parameter values in order to choose one, optimum set characterising the modelled medium.

- Prognosis. It gives answer to system behaviour in predicted conditions and consists in making calculations for given values of time limits.

- Presentation of simulation results. Models of ground waters usually generate many data whose interpretation may be difficult. Clear presentation, preferably in a graphical form, is important for illustrating and understanding the effects of modelling.

- Another analysis after some time. Re-analysing carried out some time after the study has been accomplished is recommended only when there is a possibility and need of verification of adopted prognostic assumptions. In this case new field data are collected to check the correctness of the prognosis. Performed analysis enables to find new system behaviours which may lead to improvement of the concept or to changes in model parameters.

Results of calculations and prognosis obtained with model studies are usually used as a basis for designing decisions or to formulate the strategy of protective actions. Presented algorithm of creation and initiation of the model guarantees, with sufficient probability, that obtained results are possibly the best reflection of behaviours of studied area.

Complex character of problems associated with groundwater flow and numerous physical and chemical processes involved make the creation of a universal model that would describe all phenomena and simulate their temporal variability 
practically impossible. Hence, most presently existing models consider, for practical reasons (hardware, time of calculations etc.), only selected problems.

\section{POSSIBILITIES OF APPLICATION OF NUMERICAL MODELS}

Application of models of pollutant transport and flow in ground waters pertain mainly to the assessment of the effect of local sources, both spatial and point, of pollution and to outlining buffer zones of water intakes and protected areas.

Local point sources of pollution are mainly dumping sites and surface and underground reservoir constructions. Application of mathematical modelling methods enables to estimate their potential effect on surrounding area in terms of: range of impact and concentration of substances in water and soil. It is also possible to predict temporal changes of these values. In the case of reservoir constructions it is also possible to simulate their damage and possible environmental consequences for soil-water habitat.

As for dispersed sources of pollution, mathematical modelling methods are applicable mainly in croplands. Plant protective chemicals may exert significant impact on the quality of ground and surface water resources. To estimate the amount of substances polluting the groundwater system it is necessary to recognise their transport and transformation in the plant-soil-water system. Mathematical modelling enables to determine interactions among various processes with the consideration of the effect of land use, water management and farming activities.

Dispersion models of groundwater cycling which solve together the dispersion (migration and interaction of substances with environment) and movement (filtration) equations may be used to define buffer zone around intakes of these waters (MACIOSZCZYK et al., 1993). For regional systems, due to complicated and often heterogeneous hydrogeologic conditions, the equations might be hard to solve. The reasons include numerical problems and mainly poor understanding of the systems as to spatial and nonlinear parameter distribution and spatial and temporal distribution of edge conditions. For simplicity, three dimensional modelling is reduced in these applications to plane or to quasi spatial modelling (ŚLESICKA, 2007).

\section{MATHEMATICAL MODELLING AND GEOGRAPHIC INFORMATION SYSTEMS (GIS)}

Significant, though indirect application of mathematical modelling is its use for the enlargement of information gathered in the process of recognition and assessment of conditions that prevail in soil-water environment. Results of modelling, if appropriately presented, could be an important element of decision support in environmental management. 
In the projects of protection of soil-water environment there is a need to combine and process large amount of information from various disciplines to estimate parameters of phenomena and to determine the range and time table of necessary undertakings. GIS might be a powerful tool in environmental management. Properly configured GIS might be an effective part of the decision support system by combining visualisation tools with databases. Data in tabular and graphic forms may be used to perform spatial analysis and to select the best scenarios.

GIS and computer aided design and drafting systems (CADD) might be combined with models of three dimensional flow and transport of pollutants in ground waters forming a complex decision supporting system intended to manage the projects of soil and groundwater protection.

GIS is a useful tool to combine tabular data on pollutants ("what") with spatial characteristics ("where") with the consideration of temporal changes ("when"). In combined use of three dimensional CADD programmes and three dimensional models of ground waters, GIS is an indispensable tool for collecting and analysing data on environmental status. Combined consideration of past and predicted data enables to consider time as the fourth dimension by creating animated sequences.

The main task of decision support system is to enable the user performing „experiments" with a model and studying the effect of undertaken decisions on modelled object in order to select desired scenarios. To make such a system for environmental protection of ground waters one should:

- integrate hydrologic models with CADD and GIS programmes,

- combine three dimensional hydrologic models with CADD programme,

- perform three dimensional spatial analysis with GIS,

- use animation techniques to present temporal changes (forth dimension).

In the decision support system, GIS plays crucial role for hydrogeological and hydrological applications since it enables both data management and their three dimensional visualisation. GIS is a set of spatial operators that allows combining spatial databases with geographic information. Models of GIS databases have a complex character since they must include data and relations both graphic (map) and tabular (attributes). GIS allows the user to combine tabular information (in a form of calculation sheet or database) with graphic objects in a map or CADD graph. The user may combine and process that information to solve problems like:

- determination of the usefulness of various objects for study,

- identification of ground and geologic formations in which ground waters may be especially sensitive to pollution,

- analysis of the risk of surface and subsurface water pollution in the vicinity of croplands or waste dumping sites.

GIS enables integration of data in effective way with a possibility of various approach to browsing and analysing these data. Information contained in tabular database may be available through a map or a map can be created based on infor- 
mation from tabular database. The map may be made based on data of polluted areas with the distinction of types and extent of pollution.

Fourth dimension describing temporal changes is added to the model by integration with the programme of computer animation. Graphic and tabular output describes only the status of the system in a given moment. Incorporation of momentary results into an animated sequence usually gives clearer illustration of pollutant dispersion and results of undertaken protective measures. Properties of three dimensional graph processing (change of the observation angle, size reduction or enlargement, creation perspective views etc.) available in CADD programme enable their use in the technology of creating animated sequences.

Integration of described components allows for circumventing their individual limitations and includes processes presented in Fig. 1.

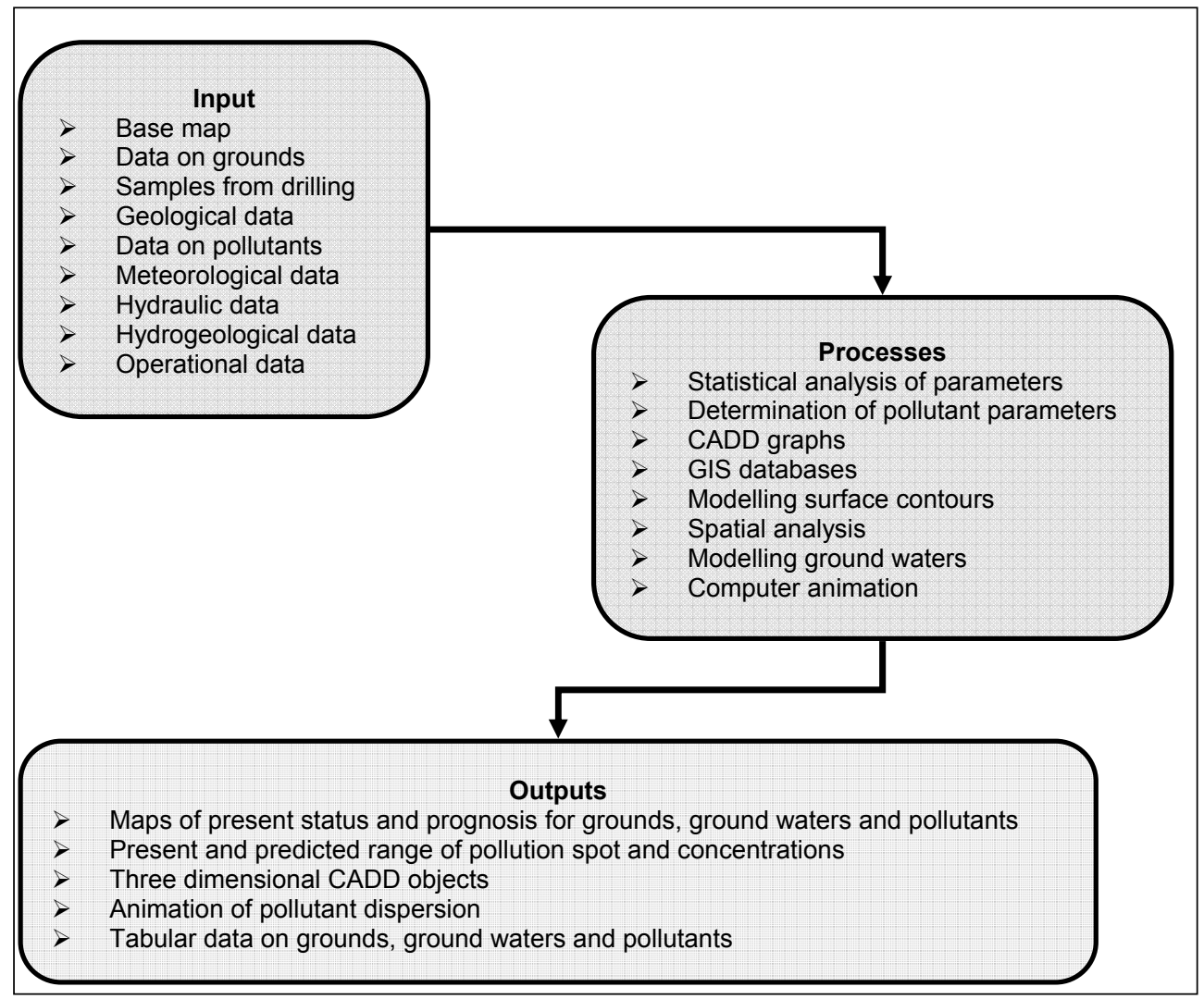

Fig. 1. General scheme of the decision support system

Combined use of three dimensional models of inflow and transport of pollutants in ground waters and GIS programmes has been recently the most intensively 
developed direction of studies. Some of the existing commercial programmes (e.g. MIKE SHE) have already built-in interfaces that allow for direct transfer of modelling results to GIS systems.

\section{REFERENCES}

1. FIC M., ŚLESICKI M., 2001. Wykorzystanie metod modelowania matematycznego do oceny oddziaływania wylewiska ścieków komunalnych na wody podziemne. (The use of mathematical modelling methods in evaluation of the effect of dumping site of municipal waste waters on ground waters). Zesz. Probl. Post. Nauk Rol., 475: 415-429.

2. GutOWSKA-SiWIEC L., ŚLESICKI M., 2002. Mathematical modelling of contaminant flow and transport in ground waters. Env. Protect. Eng., 28, 1: 43-48.

3. MAcIOSZCZYK T., RodZOch A., FrĄCZEK E., 1993. Projektowanie stref ochronnych źródeł i ujęć wód podziemnych. (Designing buffer zones of sources and intakes of ground waters). Warszawa, MOŚZNiL.

4. Poradnik. Metody badania i rozpoznawania wpływu na środowisko gruntowo-wodne składowisk odpadów stałych (Handbook. Methods of studying the effect of solid wastes dumping sites on soilwater environment), 2000. Warszawa, MŚ.

5. ŚLESICKA A., 2007. Prognozowanie wpływu przekształceń sieci hydrograficznej na zasoby wód podziemnych metodą modelowania matematycznego. W: Modelowanie matematyczne wód podziemnych. Przykłady zastosowan. (Predicting the effect of hydrographic network transformation on groundwater resources with the method of mathematical modelling). Warszawa, Eur. Centr. Ekol. Pol. Kom. IWA: $87-184$.

6. ŚLESICKI M., 2007. Trójwymiarowy model przepływu i transportu zanieczyszczeń chemicznych w wodach podziemnych. W: Modelowanie matematyczne wód podziemnych. Przykłady zastosowań. (Three dimensional model of flow and transport of chemical pollutants in ground waters). Warszawa, Eur. Centr. Ekol., Pol. Kom. IWA: 185-288.

7. ŚLESICKI M., 2007. Opracowanie i zastosowanie systemu wspomagania decyzji w ochronie środowiska wód podziemnych. W: Modelowanie matematyczne wód podziemnych. Przykłady zastosowań. (Elaboration and application of decision support system in the protection of ground water environment). Warszawa, Eur. Centr. Ekol., Pol. Kom. IWA: 341-417.

\section{STRESZCZENIE}

\section{Zastosowanie metod modelowania matematycznego w ochronie środowiska wód podziemnych}

Słowa kluczowe: modelowanie matematyczne, ochrona środowiska, transport zanieczyszczeń, wody podziemne

W projektach ochrony środowiska wód podziemnych konieczne jest stosowanie narzędzi umożliwiających łączenie i przetwarzanie znacznych ilości informacji pochodzących $\mathrm{z}$ różnych dziedzin, w celu oszacowania parametrów zjawisk oraz ustalenia zakresu i harmonogramu potrzebnych przedsięwzięć w tym zakresie. 
Modelowanie matematyczne dzięki kompleksowej ocenie procesów zachodzących w systemach wodonośnych jest najlepszym narzędziem wspomagającym w ocenie stopnia zanieczyszczenia środowiska wodno-gruntowego. Jest ono również skuteczną metodą prognozowania ryzyka, związanego ze szkodliwym oddziaływaniem obiektów zanieczyszczających grunty i wody podziemne.

Istotnym zastosowaniem modelowania matematycznego jest jego wykorzystanie do poszerzenia zakresu dostępnej informacji gromadzonej w procesie rozpoznawania i oceny warunków panujących w środowisku gruntowo-wodnym. Wyniki modelowania, w odpowiednim ujęciu, mogą być istotnym składnikiem systemu wspomagania decyzji w zakresie zarządzania ochroną środowiska.

$\mathrm{W}$ artykule przedstawiono procedurę tworzenia sytemu wspomagania decyzji w ochronie środowiska wód podziemnych bazującą na łącznym wykorzystaniu oprogramowania CADD, GIS oraz hydrogeologicznych modeli przepływu i transportu.

Reviewers:

Msc. Edmund Tusiński

Dr Andrzej Wita 